\title{
FIRST EUROPEAN CONGRESS OF RHEUMATOLOGY
}

Four hundred delegates, representing twenty-five countries, met in Copenhagen from September 3 to 8,1947 , at the first European Congress of Rheumatology under the presidency of Prof. C. Holten of Aarhus. Guests of the Congress were also present from Egypt, America, and Canada.

At a meeting held before the Congress, a European section of the International League against Rheumatism was formed on the same lines as the Pan-American section established during the war. Dr. M. P. Weil of Paris was elected the first President, and Dr. W. S. C. Copeman (Great Britain) and Prof. B. Prusik of Prague Vice-presidents: the SecretaryGeneral and Secretary are respectively Prof. E. Jarlov and Dr. K. Kalbak, both of Denmark. It is hoped that the next Congress of this body will be held in Prague in the coming year.

At the opening session, in the great Town Hall, H.M. the Queen of Denmark was represented by H.R.H. Princess Caroline Mathilde.

In his inaugural address the President referred to the public interest in this group of diseases and the demand for action. To aid in this respect was the object of the new body; it aimed at the exchange of current knowledge between the countries interested and the organization of team investigation in every country through their National branches.

The outstanding contribution in the session which followed was that of G. D. Kersley (Great Britain) on the morbid anatomy and histology of rheumatic lesions. He confirmed the work of Freund and others in 1946 as to the existence of a specific type of lesion in rheumatoid arthritis which occurred in any or all of the muscles of the body at any stage of the disease, as well as in other mesodermal tissues and around the peripheral nerves. The lesion consisted in a perivascular accumulation of lymphocytes with degenerative and proliferative changes in all the coats of the small blood vessels and degenerative changes in the muscle fibres. He also spoke of nodule formation in various types of rheumatism; he suggested the probability of a dual pathology in " fibrositis".

The majority of the scientific contributions dealt with the question of the anti-streptolysin titre and similar antibody responses in both rheumatic fever and rheumatoid arthritis; notable amongst these were the papers of
Winblad (Sweden), Kalbak (Denmark), and Svartz (Sweden). Jonsson and Palmborg (Sweden) submitted a valuable critical study, another outstanding contribution coming from van Dam (Netherlands).

The next session under the chairmanship of W. S. C. Copeman (Great Britain) was devoted to the treatment of rheumatoid arthritis by means of gold salts and chemotherapy. This was introduced by a useful contribution by O. Steinbrocker (U.S.A.). A full exposure of the subject by Forestier was presented by Coste (France), and confirmation of the value of various gold salts in rheumatoid arthritis came from papers by both Secher and Clemmeson (Denmark), Sunderlin (Sweden), Kuipers (Holland), and Dobelie (Switzerland). Much less optimistic accounts came from Schlesinger (Great Britain), who was speaking principally of Still's disease, and from some speakers in the discussion. New work reported by Svartz (Sweden) on treatment of arthritis with sulphonamides still awaits confirmation.

The third and fourth sessions, under the chairmanship respectively of F. Coste (France) and van Breemen (Holland), dealt with various aspects of the social background of the rheumatic diseases and with the outstanding biochemical problems of rheumatism. In the former category important statistics were produced from France, Sweden, Switzerland, Denmark, and Eire, whilst under the latter heading papers were read by Delore and Milhaud (France), Edström and others (Sweden), and Dirisu (Turkey). Papers, which were limited to ten minutes, were also presented on various other subjects by a number of delegates including representatives of Belgium, Switzerland, and Czechoslovakia. Steinbrocker (U.S.A.) gave an important paper on the shoulder-hand syndrome in reflex dystrophy of the upper extremity.

The Congress then moved from Copenhagen to the University of Aarhus on the mainland; here it split up into two sections, where reports of personal investigations into various aspects of rheumatism were briefly presented. These included liver tests in rheumatism, studies in the peripheral circulation of rheumatic subjects, food allergy in rheumatoid arthritis, dental infection and joint disease in mediaeval Denmark, rheumatic fever amongst the partisan forces of Yugoslavia, jaundice as a "rheumatic" disease in Poland, and the role of wound sepsis in unmasking rheumatic syndromes during the war in Rumania. 